See discussions, stats, and author profiles for this publication at: https://www.researchgate.net/publication/295253375

\title{
Effects of chitosan on ruminal fermentation, nutrient digestibility, and milk yield and composition of dairy cows
}

Article in Animal Production Science · January 2016

DOI: $10.1071 /$ AN15329

\section{CITATIONS}

9

10 authors, including:

P.G. Paiva

Universidade Estadual Paulista 'Julio de Mesquita Filho"

21 PUBLICATIONS 98 CITATIONS

SEE PROFILE

Tiago Del Valle

Universidade Federal do Pampa (Unipampa)

44 PUBLICATIONS 89 CITATIONS

SEE PROFILE
READS

656

Elmeson Ferreira de Jesus

25 PUBLICATIONS 83 CITATIONS

SEE PROFILE

Q Carlos Cardoso Consentini

University of São Paulo

7 PUBlications 36 Citations

SEE PROFILE

Some of the authors of this publication are also working on these related projects:

Project INTERACTIONS OF THE SOIL-CROP-ANIMAL-ATMOSPHERE COMPONENTS IN INTEGRATED CROP-LIVESTOCK SYSTEMS WITH SHEEP VieW PROject

Project Resposta morfológica das mucosas ruminal e omasal à variação alimentar View project 


\title{
Effects of chitosan on ruminal fermentation, nutrient digestibility, and milk yield and composition of dairy cows
}

\author{
Pablo Gomes de Paiva ${ }^{\mathrm{A}}$, Elmeson Ferreira de Jesus ${ }^{\mathrm{A}}$, Tiago Antonio Del Valle ${ }^{\mathrm{B}}$, \\ Gustavo Ferreira de Almeida ${ }^{\mathrm{B}}$, Artur Gabriel Brao Vilas Boas Costa ${ }^{\mathrm{B}}$, \\ Carlos Eduardo Cardoso Consentini ${ }^{\mathrm{B}}$, Filipe Zanferari ${ }^{\mathrm{B}}$, Caio Seiti Takiya ${ }^{\mathrm{B}}$, \\ Ives Cláudio da Silva Bueno ${ }^{\mathrm{C}}$ and Francisco Palma Rennó ${ }^{\mathrm{B}, \mathrm{D}}$ \\ ADepartment of Animal Sciences, UNESP - Universidade Estadual Paulista ‘Júlio de Mesquita Filho' /Campus \\ Jaboticabal, Rod. Prof. Paulo Donato Castellane km 5, Jaboticabal, SP, 14884900, Brazil. \\ ${ }^{B}$ Department of Animal Nutrition and Production, School of Veterinary Medicine and Animal Sciences, University \\ of São Paulo (USP), Av. Duque de Caxias Norte, 225-Campus da USP, Pirassununga, SP, 13635900, Brazil. \\ ${ }^{C}$ Department of Animal Sciences, Faculty of Animal Science and Food Engineering, University of São Paulo (USP), \\ Av. Duque de Caxias Norte, 225-Campus da USP, Pirassununga, SP, 136359000, Brazil. \\ DCorresponding author. Email: francisco.renno@usp.br
}

\begin{abstract}
Our objective was to evaluate the effects of providing increasing levels of chitosan on nutrient digestibility, ruminal fermentation, blood parameters, nitrogen utilisation, microbial protein synthesis, and milk yield and composition of lactating dairy cows. Eight rumen-fistulated Holstein cows [average days in lactation $=215 \pm 60.9$; and average bodyweight $(\mathrm{BW})=641 \pm 41.1 \mathrm{~kg}$ ] were assigned into a replicated $4 \times 4$ Latin square design, with 21-day evaluation periods. Cows were assigned to be provided with four levels of chitosan, placed into the rumen through the fistula, as follows: (1) Control: with no provision of chitosan; (2) $75 \mathrm{mg} / \mathrm{kg} \mathrm{BW}$; (3) $150 \mathrm{mg} / \mathrm{kg} \mathrm{BW}$; and (4) $225 \mathrm{mg} / \mathrm{kg}$ BW. Chitosan had no effect on dry matter intake $(P>0.73)$; however, chitosan increased $(P=0.05)$ crude protein digestibility. Propionate concentration was increased $(P=0.02)$, and butyrate, isobutyrate, isovalerate and acetate: propionate ratio were decreased $(P \leq 0.04)$ by chitosan. Chitosan had no effect $(P>0.25)$ on acetate, $\mathrm{pH}$ and $\mathrm{NH}_{3}$ ruminal concentration. Glucose, urea, and hepatic enzyme concentrations in the blood were similar $(P>0.30)$ among treatments. Nitrogen balance was not affected, but chitosan increased milk nitrogen $(P=0.02)$. Microbial protein synthesis was not affected by chitosan $(P>0.44)$. Chitosan increased $(P=0.02)$ milk yield, fat-corrected milk, protein and lactose production. Chitosan changes ruminal fermentation and improves milk yield of lactating dairy cows; therefore, we conclude that chitosan can be used as a rumen modulator instead of ionophores in diets for dairy cows.
\end{abstract}

Additional keywords: additive, antimicrobial, dry matter intake.

Received 23 June 2015, accepted 6 October 2015, published online 18 February 2016

\section{Introduction}

Meeting requirements of high-production dairy cows is a great challenge for nutritionists. Modulating ruminal fermentation using feed additives is a reality (Calsamiglia et al. 2007; Goiri et al. 2010), and ionophores are frequently used to improve ruminant nutrient utilisation. Despite the fact that ionophores are the major class of additive used in diets, their use has been reviewed and restricted due to their potential effect on microbial resistance to antibiotics (Russell and Houlihan 2003).

Chitosan, a non-toxic and biodegradable biopolymer derived from the deacetylation of chitin, has been successfully used in the food, pharmaceutical, cosmetics and agricultural industries, especially because of its antimicrobial properties (Kong et al. 2010). In ruminant nutrition, previous in vitro studies showed that chitosan could change ruminal fermentation by shifting the volatile fatty acid (VFA) profile and increasing propionate concentration (Goiri et al. 2009a, $2009 b$ ). However, these studies also reported that chitosan had a negative effect on dry matter (DM) and neutral detergent fibre (NDF) digestibility yet Goiri et al. (2010) demonstrated that chitosan increased ruminal propionate concentration without any effect on digestibility in sheep and shifted ruminal fermentation to more efficient routes. Thus, given the importance of ruminal fermentation on metabolism and performance of ruminants, and possible use of chitosan as an alternative to ionophores, more in vivo studies are necessary to identify the effect of chitosan, mainly in dairy cow diets. Therefore, our objective was to evaluate the effects of chitosan levels on nutrient intake and digestibility, ruminal fermentation, blood parameters, nitrogen $(\mathrm{N})$ utilisation, microbial protein synthesis and milk yield and composition of late-lactating cows. 


\section{Materials and methods}

This study was approved by the Bioethics Committee of the School of Veterinary Medicine and Animal Sciences of the University of Sao Paulo (approval number: 3057/2013).

\section{Animals, experimental design and treatments}

Eight rumen-fistulated Holstein cows [average $215.4 \pm 60.9$ days in lactation and average $641.6 \pm 41.1 \mathrm{~kg}$ of bodyweight (BW)] were assigned into a replicated $4 \times 4$ Latin square design based on initial milk yield and BW. Each experimental period consisted of 21 days, with 14 days of acclimation to treatments and the last 7 days for data collection. Cows were assigned within each square to be provided with one of four levels of chitosan, as follows: (1) Control: with no provision of chitosan; (2) $75 \mathrm{mg} / \mathrm{kg} \mathrm{BW}$; (3) $150 \mathrm{mg} / \mathrm{kg} \mathrm{BW}$; and (4) $225 \mathrm{mg} / \mathrm{kg} \mathrm{BW}$.

Chitosan used in this study, purchased from a private company (Polymar Indústria, Comércio Importação e Exportação LTDA, Fortaleza, Ceara, Brazil), had $0.33 \mathrm{~g} / \mathrm{mL}$ of apparent density, $\mathrm{pH}=7.9$, viscosity $<200 \mathrm{cPs}$, deacetylation degree of $86.3 \% ; 1.4 \%$ ash, and $88.3 \%$ of DM. The amount of chitosan provided for each cow was daily weighed, packed in paper bags, and placed into the rumen via the fistula, twice daily, at 0800 hours and 1600 hours. Control-based diet was formulated according to NRC (2001; Table 1), and cows were fed a total mixed ration, twice daily at 0700 hours and 1300 hours to provide $105-110 \%$ of the expected feed intake. Animals were housed in individual pens of $17.5 \mathrm{~m}^{2}$ with sand beds and forced ventilation, and had free access to water. Throughout the experimental period, BW was measured in

Table 1. Ingredients and chemical composition of the controlbased diet

\begin{tabular}{|c|c|}
\hline Item & Control diet \\
\hline \multicolumn{2}{|c|}{ Ingredients $(\% D M)$} \\
\hline Corn silage & 63.08 \\
\hline Ground corn & 22.52 \\
\hline Soybean meal & 11.50 \\
\hline Urea & 0.75 \\
\hline Ammonium sulfate & 0.15 \\
\hline Mineral premix ${ }^{\mathrm{A}}$ & 1.80 \\
\hline Salt & 0.20 \\
\hline \multicolumn{2}{|c|}{ Chemical composition $(\% D M)$} \\
\hline Dry matter (\% as fed) & 52.79 \\
\hline Organic matter & 94.07 \\
\hline Crude protein & 14.90 \\
\hline Ether extract & 2.89 \\
\hline Non-fibrous carbohydrate ${ }^{\mathrm{B}}$ & 38.11 \\
\hline Neutral detergent fibre & 39.74 \\
\hline Net energy ${ }^{\mathrm{C}}(\mathrm{Mcal} / \mathrm{kg} \mathrm{DM})$ & 1.67 \\
\hline
\end{tabular}

${ }^{\mathrm{A}}$ Composition (per kg): $88.0 \mathrm{~g}$ of Ca; $42.0 \mathrm{~g}$ of P; $18.0 \mathrm{~g}$ of S; $45.0 \mathrm{~g}$ of Mg; $123.0 \mathrm{~g}$ of $\mathrm{Na} ; 14.0 \mathrm{mg}$ of $\mathrm{Co} ; 500.0 \mathrm{mg}$ of $\mathrm{Cu} ; 20.0 \mathrm{mg}$ of $\mathrm{Cr} ; 1050.0 \mathrm{mg}$ of Fe; $28.0 \mathrm{mg}$ of I; $1400.0 \mathrm{mg}$ of Mn; $18.0 \mathrm{mg}$ of Se; $2800.0 \mathrm{mg}$ de $\mathrm{Zn}$; $80.0 \mathrm{mg}$ of Biotin; 200.00000 IU Vit A; 40.00000 IU Vit D; 1.20000 IU Vit E.

${ }^{\mathrm{B}} \mathrm{NFC}=100-[(\mathrm{CP}-\mathrm{CP}$ of urea + urea $)+\mathrm{NDF}+\mathrm{EE}+\mathrm{ash}]$ from Hall (2000).

${ }^{\mathrm{C}}$ Estimated using the NRC (2001) model. 7-day intervals after the morning milking to allow for adjustment of chitosan provided to each cow.

\section{Sample collection and analyses}

Feed and orts samples were collected throughout the sampling period and stored at $-20^{\circ} \mathrm{C}$ until analysis. From Day 16 to 18 of each period, faecal samples were collected from each cow, after the morning and afternoon milking and combined to make a composite sample per cow. Feed, orts and faecal samples were dried in a forced-air oven at $55^{\circ} \mathrm{C}$ for $72 \mathrm{~h}$, ground to pass through a 1-mm screen (Wiley mill, Arthur H. Thomas, Philadelphia, PA, USA) and then analysed for DM (method 930.15; AOAC 2000); crude protein (CP) was obtained by multiplying total $\mathrm{N}$, determined using the micro Kjeldahl technique (method 984.13; AOAC 2000), by a fixed conversion factor (6.25); ether extract (EE) was determined gravimetrically after extraction using petroleum ether in a Soxlet apparatus (method 920.39; AOAC 2000), and ash (method 942.05; AOAC 2000). The NDF was determined according to Mertens et al. (2002) using fibre determination equipment (Ankom Tech. Corp., Fairport, NY, USA).

Indigestible acid detergent fibre (iADF) was used as an internal marker to estimate total faecal excretion and, consequently, apparent total tract digestibility of nutrient according to Casali et al. (2008). Briefly, feed, orts and faeces samples were dried at $55^{\circ} \mathrm{C}$ in a forced-air oven for $72 \mathrm{~h}$ and then ground to pass through a 2-mm screen (Wiley mill, Arthur H. Thomas). The ground material was placed in $20 \times 10-\mathrm{cm}$ non-woven textile bags (diameter of pore size $=50 \mathrm{~mm}$ and weighing $6 \mathrm{~g}$ to provide a sample weight: bag surface ratio of 10-20 mg/cm2; Nocek 1988), and incubated for a 288-h period in the rumen of two Holstein cows, previously adapted to a diet similar to the diet used in this study. After removal, bags were washed in running tap water, then dried at $55^{\circ} \mathrm{C}$ in a forced-air oven and submitted to an acid-detergent solution treatment to obtain the iADF (973.18; AOAC 2000). Digestibility was calculated using the ratio of $\mathrm{iADF}$ in feed (corrected for orts) and faeces.

\section{Ruminal fermentation parameters}

Ruminal fluid samples were collected immediately before, and 2, 4, 6, 10 and $12 \mathrm{~h}$ after the morning feeding on Day 20 of each period. The ruminal $\mathrm{pH}$ values were determined using a digital pH meter (model MB-10, Marte Cientifica, Santa Rita do Sapucai, MG, Brazil). Afterwards, ruminal fluid samples $(50 \mathrm{~mL})$ were centrifuged at $7000 \mathrm{~g}$ at $4^{\circ} \mathrm{C}$ for $15 \mathrm{~min}$. A $2-\mathrm{mL}$ supernatant aliquot was mixed with $0.4 \mathrm{~mL}$ of formic acid, and stored at $-20^{\circ} \mathrm{C}$ for analysis of VFA. Another 2-mL supernatant aliquot was mixed with $0.5 \mathrm{mmol} / \mathrm{L}$ of sulfuric acid and stored at $-20^{\circ} \mathrm{C}$ for determination of ammonia- $\mathrm{N}$ concentration by the phenol-hypochlorite method (Broderick and Kang 1980). Ruminal fluid VFA were measured using a gas chromatograph (model GC-2104, Shimadzu, Tokyo, Japan) according to the method described by Erwin et al. (1961) and adapted by Getachew et al. (2002). The gas chromatograph was equipped with a split injector and dual flame ionisation detector temperature at $250^{\circ} \mathrm{C}$ and with a capillary column 
(Stabilwax, Restek, Bellefonte, PA, USA) at $145^{\circ} \mathrm{C}$. Frozen ruminal fluid samples were thawed at room temperature and centrifuged at $14500 \mathrm{~g}$ at $4^{\circ} \mathrm{C}$ for $10 \mathrm{~min}$; then $1 \mathrm{~mL}$ of the supernatant subsamples was transferred into a clean dry vial containing $100 \mu \mathrm{L}$ of internal standard (2-ethylbutyric acid 100 mM; Chem Service Inc., West Chester, PA, USA). The gases used in the analyses were helium as the carrier gas $(8.01 \mathrm{~mL} / \mathrm{min}$ flow), hydrogen as the fuel gas (pressure of $60 \mathrm{kPa}$ ), and synthetic air as the oxidiser gas (pressure of 40 $\mathrm{kPa}$ ). External standard was prepared with acetic, propionic, isobutyric, butyric, isovaleric, and valeric acids (Chem Service). The software GCSolution (Shimadzu) was used for calculation of VFA concentrations.

\section{Blood metabolites}

On Day 15 of each period, blood samples were collected from each cow via the coccygeal vein before the morning feeding. Blood samples were centrifuged at $3000 \mathrm{~g}$ at $4^{\circ} \mathrm{C}$ for $10 \mathrm{~min}$ and plasma was separated and stored at $-20^{\circ} \mathrm{C}$ until analysis. Analyses were performed using colourimetric commercial kits (glucose: cat. no. K-082; urea: cat. no. K-056; aspartatesuccinyltransferase: cat. no. K-048; gamma-glutamyl transferase: cat. no. K-080; Bioclin, Belo Horizonte, MG, Brazil), and measurements were completed in a semi-automatic spectrophotometer (model SBA 200, CELM, Sao Caetano do Sul, SP, Brazil).

\section{Nitrogen balance and microbial protein synthesis}

On Day 16 of each period, spot urine samples were collected from each cow $4 \mathrm{~h}$ after the morning feeding. Urine samples were filtered and $10-\mathrm{mL}$ aliquots were immediately diluted in $40 \mathrm{~mL}$ of $0.036 \mathrm{~N}$ sulfuric acid, and stored at $-20^{\circ} \mathrm{C}$ for uric acid and allantoin analyses. A pure urine sample was stored for total $\mathrm{N}$ and creatinine analyses. Concentrations of uric acid and creatinine were measured by using biochemical commercial kits (uric acid stable liquid: cat. no. K-0.52; kinetic creatinine: cat. no. K-067; Bioclin), in a semi-automatic spectrophotometer (model SBA 200, CELM). The daily urine volume was estimated from the daily creatinine as $24.05 \mathrm{mg} / \mathrm{kg}$ of BW (Chizzotti et al.
2008). The excretion of uric acid and allantoin in the urine and milk (Fujihara and Yamaguchi 1978), were considered as the total excretion of purine derivatives, and microbial protein synthesis was estimated from these concentrations according to Chen and Gomes (1992). Total N in urine samples was determined (method 984.13; AOAC 2000), and N balance was calculated according to the NRC (2001) model.

\section{Milk yield and composition}

Cows were milked twice daily, at 0600 hours and 1600 hours, and milk yield was measured with an automatic milk meter (model Alpro, DeLaval, Tumba, Sweden). From Day 16 to 18 of each period, milk samples were automatically collected (model Alpro), according to the milk yield of each cow and of each milking. Fresh milk samples were analysed for CP, fat, and lactose using an ultrasonic milk analyser (model MCC, Milkotronic Ltd, Nova Zagora, Bulgaria). Milk yield was corrected to $3.5 \%$ fat according to Sklan et al. (1992).

\section{Statistical analyses}

Data were analysed using the MIXED procedure of SAS (SAS Institute Inc., Cary, NC, USA, version 9.0), according to the statistical model:

$$
Y_{i j k}=\mu+S_{i}+P_{j}+T_{k}+A_{l}\left(S_{i}\right)+e_{i j k},
$$

where $Y_{i j k}=$ dependent variable, $\mu=$ overall mean, $S_{i}=$ fixed effect of square, $P_{j}=$ fixed effect of period, $T_{k}=$ fixed effect of treatment, $A_{l}\left(S_{i}\right)$ random effect of animal within square and $e_{i j k}=$ residual error. Ruminal fermentation variables $(\mathrm{pH}$, $\mathrm{NH}_{3}-\mathrm{N}$, and VFA) were analysed as repeated using the MIXED procedure of SAS. The statistical model included the effects of animal, period, square, treatment, time and time*treatment interaction. Compound symmetry was the best covariance structure based upon the smallest Akaike's information criterion values. Other covariance structures tested included heterogeneous compound symmetry, unstructured, autoregressive 1 and heterogeneous autoregressive 1. Data were subjected to ANOVA, polynomial regression, and means

Table 2. Effects of increasing levels of chitosan on dry matter intake and nutrient digestibility of lactating cows a,b, Least-squares mean within a row with different letters differ $(P \leq 0.05)$

\begin{tabular}{|c|c|c|c|c|c|c|c|}
\hline \multirow[t]{2}{*}{ Item } & \multicolumn{4}{|c|}{ Treatment $^{\mathrm{A}}$} & \multirow[t]{2}{*}{ s.e.m. } & \multicolumn{2}{|c|}{$P$-value ${ }^{\mathrm{B}}$} \\
\hline & 0 & 75 & 150 & 225 & & LIN & QUA \\
\hline Dry matter intake (kg/day) & 19.8 & 20.3 & 19.4 & 20.2 & 0.47 & 0.79 & 0.57 \\
\hline Dry matter intake (\%BW) & 3.0 & 3.0 & 2.9 & 3.0 & 0.08 & 0.73 & 0.47 \\
\hline \multicolumn{8}{|c|}{ Coefficient of digestibility $(\mathrm{kg} / \mathrm{kg})$} \\
\hline Dry matter & 0.650 & 0.660 & 0.670 & 0.670 & 0.0009 & 0.29 & 0.66 \\
\hline Organic matter & 0.670 & 0.680 & 0.690 & 0.690 & 0.0001 & 0.24 & 0.56 \\
\hline Crude protein & $0.700 \mathrm{~b}$ & $0.720 \mathrm{ab}$ & $0.731 \mathrm{a}$ & $0.731 \mathrm{a}$ & 0.0009 & 0.05 & 0.39 \\
\hline Ether extract & 0.761 & 0.801 & 0.781 & 0.810 & 0.0009 & 0.16 & 0.66 \\
\hline Neutral detergent fibre & 0.601 & 0.570 & 0.590 & 0.580 & 0.0011 & 0.47 & 0.36 \\
\hline
\end{tabular}

${ }^{\mathrm{A}}$ Four treatments were evaluated: (1) Control: with no provision of chitosan; (2) $75 \mathrm{mg} / \mathrm{kg} \mathrm{BW}$; (3) $150 \mathrm{mg} / \mathrm{kg} \mathrm{BW}$; and (4) $225 \mathrm{mg} / \mathrm{kg} \mathrm{BW}$ of chitosan placed into the rumen through the fistula.

${ }^{\mathrm{B}}$ Linear (LIN) or quadratic (QUA) effects. 
were separated with LSMEANS, adjusted with Tukey; significance level was set at $P<0.05$.

\section{Results}

Feed intake and nutrient digestibility

Dry matter intake $(\mathrm{kg} /$ day and \%BW) did not differ $(P \geq 0.47)$ among treatments (Table 2). Chitosan provision did not affect $(P \geq 0.16)$ DM, organic matter, EE and NDF digestibility. However, chitosan linearly increased $(P=0.05)$ $\mathrm{CP}$ digestibility, and the greatest values were observed in cows provided with 150 and $225 \mathrm{mg} / \mathrm{kg} \mathrm{BW}$ of chitosan.

\section{Ruminal fermentation parameters}

Chitosan provision did not affect $(P \geq 0.25)$ ruminal $\mathrm{pH}$ and $\mathrm{NH}_{3}$ concentrations (Table 3). There was no chitosan effect $(P \geq 0.25)$ on total VFA, acetate, isobutyrate and valerate concentrations. However, chitosan linearly increased $(P=0.02)$ propionate concentrations, and when values were compared by Tukey test, the $225 \mathrm{mg} / \mathrm{kg} \mathrm{BW}$ treatment had the greatest concentration $(P=0.05)$. Ruminal butyrate concentration linearly decreased $(P=0.03)$ with increased chitosan provision and the greatest value was observed in the $75 \mathrm{mg} / \mathrm{kg} \mathrm{BW}$ treatment. Isovalerate concentration linearly decreased $(P<0.01)$ with increased chitosan provision. Acetate: propionate ratio linearly reduced $(P=0.01)$ with increased chitosan, and the least value was observed in the $225 \mathrm{mg} / \mathrm{kg}$ BW treatment.

\section{Blood metabolites, $N$ balance and microbial protein synthesis}

Blood concentrations of glucose, urea, aspartatesuccinyltransferase and gamma-glutamyl transferase were not altered $(P \geq 0.30)$ by chitosan provision (Table 4$)$. The $\mathrm{N}$ intake, excretion in urine and faeces and balance did not differ $(P \geq 0.09)$ among treatments. However, chitosan linearly increased $(P=0.02)$ milk $\mathrm{N}$ and milk $\mathrm{N}: \mathrm{N}$ intake ratio, with the greatest values observed in the $225 \mathrm{mg} / \mathrm{kg}$ BW treatment.
Microbial N, CP and efficiency were not affected $(P \geq 0.44)$ by chitosan provision.

\section{Milk yield and composition}

Chitosan provision linearly increased $(P=0.02)$ milk, protein and lactose yield with the greatest values observed in the $225 \mathrm{mg} / \mathrm{kg} \mathrm{BW}$ treatment (Table 5). The fat-corrected milk, fat yield and fat, protein and lactose content in milk were not affected $(P \geq 0.16)$. Efficiency of milk production (kg milk/ $\mathrm{kg}$ DM intake) did not differ $(P \geq 0.18)$ among treatments.

\section{Discussion}

Despite the fact that chitosan did not affect DM intake, the CP digestibility was improved when cows were provided with chitosan. Araújo et al. (2015) reported a linear increase of DM, NDF and CP digestibility without changes in DM intake following provision of increasing doses of chitosan to Nellore steers; however, the authors suggested that the increase of $\mathrm{CP}$ digestibility was due to altered fermentation. The mechanism by which chitosan alters $\mathrm{CP}$ digestibility is unclear, but can be related to absorption of peptides in the duodenum or the amounts of amino acids escaping ruminal fermentation, once $\mathrm{NH}_{3}$ ruminal concentration and microbial synthesis were not altered. Some additives can enhance the efficiency of $\mathrm{N}$ utilisation by reducing amino acids ruminal deamination rate (Yang and Russell 1993), allowing more amino acids to reach the duodenum for absorption.

There have been several studies examining the effect of chitosan on rumen fermentation, published in the past decade (Goiri et al. 2009a, 2010; Araújo et al. 2015). Goiri et al. (2010) reported an increase of in vitro propionate and decrease in acetate concentrations when chitosan was used in a substrate of starch but not in cellulose substrate. In the present study, the digestibility of non-fibrous carbohydrate increased (data not shown) for cows provided with chitosan, which could explain the greater propionate production of cows. Araújo et al. (2015) also observed a linear increase of propionate concentration when feeding increasing doses of chitosan, and the diet used was similar to the diet of the present study. Furthermore, the

Table 3. Effects of increasing levels of chitosan on ruminal fermentation parameters of lactating cows a,b, Least-squares mean within a row with different letters differ $(P \leq 0.05)$

\begin{tabular}{|c|c|c|c|c|c|c|c|c|c|c|}
\hline \multirow[t]{2}{*}{ Item } & \multicolumn{4}{|c|}{ Treatment $^{\mathrm{A}}$} & \multirow[t]{2}{*}{ s.e.m. } & \multicolumn{5}{|c|}{$P$-value ${ }^{\mathrm{B}}$} \\
\hline & 0 & 75 & 150 & 225 & & $\mathrm{CHI}$ & Time & Int & LIN & QUA \\
\hline $\mathrm{pH}$ & 6.42 & 6.42 & 6.38 & 6.34 & 0.043 & 0.67 & $<0.01$ & 0.40 & 0.25 & 0.70 \\
\hline $\mathrm{NH}_{3}(\mathrm{mg} / \mathrm{dL})$ & 26.70 & 24.11 & 25.64 & 26.93 & 0.701 & 0.69 & 0.77 & 0.71 & 0.79 & 0.30 \\
\hline Total volatile fatty acids (mM) & 109.56 & 103.90 & 104.53 & 105.27 & 2.076 & 0.65 & $<0.01$ & 0.65 & 0.43 & 0.36 \\
\hline Acetate $(\mathrm{mM})$ & 72.29 & 66.08 & 68.01 & 67.42 & 1.412 & 0.24 & $<0.01$ & 0.26 & 0.20 & 0.21 \\
\hline Propionate (mM) & $19.65 b$ & $19.60 \mathrm{~b}$ & $21.56 \mathrm{~b}$ & $23.25 \mathrm{a}$ & 0.484 & 0.09 & $<0.01$ & 0.07 & 0.02 & 0.43 \\
\hline Butyrate $(\mathrm{mM})$ & $11.69 \mathrm{~b}$ & $13.14 \mathrm{a}$ & $10.73 b$ & $10.33 b$ & 0.273 & 0.02 & $<0.01$ & 0.72 & 0.03 & 0.15 \\
\hline Valerate (mM) & 1.52 & 1.49 & 1.47 & 1.55 & 0.048 & 0.93 & $<0.01$ & 0.46 & 0.86 & 0.58 \\
\hline Isobutyrate (mM) & $1.16 \mathrm{a}$ & $1.11 \mathrm{a}$ & $1.02 \mathrm{~b}$ & $1.02 \mathrm{~b}$ & 0.044 & 0.17 & 0.22 & 0.59 & 0.04 & 0.64 \\
\hline Isovalerate (mM) & 2.52 & 2.21 & 1.88 & 1.80 & 0.053 & $<0.01$ & $<0.01$ & 0.26 & $<0.01$ & 0.19 \\
\hline Acetate: propionate ratio & 3.67 & 3.47 & 3.25 & 3.01 & 0.042 & 0.01 & 0.04 & 0.06 & 0.01 & 0.86 \\
\hline
\end{tabular}

\footnotetext{
${ }^{A}$ Four treatments were evaluated: (1) Control: with no provision of chitosan; (2) $75 \mathrm{mg} / \mathrm{kg} \mathrm{BW}$; (3) $150 \mathrm{mg} / \mathrm{kg} \mathrm{BW}$; and (4) $225 \mathrm{mg} / \mathrm{kg} \mathrm{BW}$ of chitosan placed into the rumen through the fistula.

${ }^{\mathrm{B}}$ Effects of chitosan (CHI), time, chitosan * time (Int), and linear (LIN) or quadratic (QUA) effects.
} 
Table 4. Effects of increasing levels of chitosan on blood parameters and nitrogen balance of lactating cows a,b, Least-squares mean within a row with different letters differ $(P \leq 0.05)$. AST, aspartate-succinyltransferase (units per litre); GGT, gamma-glutamyltransferase (units per litre)

\begin{tabular}{|c|c|c|c|c|c|c|c|}
\hline \multirow[t]{2}{*}{ Item } & \multicolumn{4}{|c|}{ Treatment $^{\mathrm{A}}$} & \multirow[t]{2}{*}{ s.e.m. } & \multicolumn{2}{|c|}{$P$-value ${ }^{\mathrm{B}}$} \\
\hline & 0 & 75 & 150 & 225 & & LIN & QUA \\
\hline \multicolumn{8}{|c|}{ Blood metabolites } \\
\hline Glucose (mg/dL) & 83.5 & 80.7 & 78.7 & 77.3 & 2.62 & 0.30 & 0.87 \\
\hline Urea $(\mathrm{mg} / \mathrm{dL})$ & 30.7 & 29.9 & 27.9 & 29.5 & 1.25 & 0.49 & 0.52 \\
\hline AST (U/L) & 58.1 & 62.6 & 60.0 & 60.4 & 1.75 & 0.69 & 0.41 \\
\hline GGT (U/L) & 37.4 & 32.4 & 37.1 & 32.3 & 2.44 & 0.52 & 0.99 \\
\hline \multicolumn{8}{|c|}{ Nitrogen balance ( $g /$ day) } \\
\hline $\mathrm{N}$ intake & 491.3 & 503.1 & 481.3 & 500.0 & 11.79 & 0.92 & 0.72 \\
\hline Urinary $\mathrm{N}$ & 153.1 & 141.7 & 157.8 & 155.1 & 3.98 & 0.48 & 0.54 \\
\hline Faecal N & 148.7 & 139.9 & 128.6 & 131.8 & 6.48 & 0.09 & 0.45 \\
\hline Milk N & $98.7 b$ & $100.8 \mathrm{~b}$ & $103.3 \mathrm{a}$ & $109.7 \mathrm{a}$ & 4.69 & 0.02 & 0.49 \\
\hline $\mathrm{N}$ balance & 90.9 & 120.6 & 91.6 & 103.4 & 8.78 & 0.83 & 0.31 \\
\hline Milk N: N intake & 20.1 & 20.2 & 21.4 & 21.9 & 0.83 & 0.02 & 0.72 \\
\hline Microbial N & 224.8 & 232.6 & 227.2 & 238.4 & 7.13 & 0.44 & 0.96 \\
\hline Microbial protein & 1405.4 & 1454.1 & 1420.1 & 1490.1 & 44.58 & 0.44 & 0.96 \\
\hline Microbial efficiency ${ }^{\mathrm{C}}$ & 100.1 & 103.1 & 102.9 & 105.3 & 3.32 & 0.48 & 0.92 \\
\hline
\end{tabular}

${ }^{\mathrm{A}}$ Four treatments were evaluated: (1) Control: with no provision of chitosan; (2) $75 \mathrm{mg} / \mathrm{kg} \mathrm{BW}$; (3) $150 \mathrm{mg} / \mathrm{kg} \mathrm{BW}$; and (4) $225 \mathrm{mg} / \mathrm{kg} \mathrm{BW}$ of chitosan placed into the rumen through the fistula.

${ }^{\mathrm{B}}$ Linear (LIN) or quadratic (QUA) effects.

${ }^{\mathrm{C}}$ Microbial efficiency $=$ grams of microbial $\mathrm{N}$ per kilogram of TDN intake.

Table 5. Effects of increasing levels of chitosan on milk yield and composition of lactating cows a,b, Least square mean within a row with different letters differ $(P \leq 0.05)$

\begin{tabular}{|c|c|c|c|c|c|c|c|}
\hline \multirow[t]{2}{*}{ Item } & \multicolumn{4}{|c|}{ Treatment $^{\mathrm{A}}$} & \multirow[t]{2}{*}{ s.e.m. } & \multicolumn{2}{|c|}{$P$-value ${ }^{\mathrm{B}}$} \\
\hline & 0 & 75 & 150 & 225 & & LIN & QUA \\
\hline \multicolumn{8}{|c|}{ Yield $(\mathrm{kg} /$ day $)$} \\
\hline Milk & $20.06 \mathrm{~b}$ & $20.42 b$ & $21.10 \mathrm{~b}$ & $22.20 \mathrm{a}$ & 0.91 & 0.02 & 0.55 \\
\hline $3.5 \%$ fat-corrected milk & 24.40 & 25.33 & 25.16 & 26.24 & 1.06 & 0.16 & 0.93 \\
\hline Fat & 0.97 & 1.01 & 0.98 & 1.02 & 0.04 & 0.42 & 0.92 \\
\hline Protein & $0.63 b$ & $0.64 b$ & $0.66 \mathrm{ab}$ & $0.70 \mathrm{a}$ & 0.03 & 0.02 & 0.46 \\
\hline Lactose & $0.95 b$ & $0.96 b$ & $0.99 \mathrm{ab}$ & $1.05 \mathrm{a}$ & 0.04 & 0.02 & 0.47 \\
\hline \multicolumn{8}{|c|}{ Composition (\%) } \\
\hline Fat & 4.77 & 5.07 & 4.65 & 4.65 & 0.13 & 0.16 & 0.22 \\
\hline Protein & 3.13 & 3.15 & 3.12 & 3.14 & 0.02 & 0.86 & 0.69 \\
\hline Lactose & 4.71 & 4.72 & 4.66 & 4.70 & 0.03 & 0.45 & 0.45 \\
\hline Milk yield: dry matter intake & 1.23 & 1.27 & 1.29 & 1.30 & 0.05 & 0.18 & 0.76 \\
\hline Body condition score ${ }^{\mathrm{C}}$ & 2.78 & 2.78 & 2.78 & 2.80 & 0.03 & 0.41 & 0.48 \\
\hline
\end{tabular}

${ }^{\mathrm{A}}$ Four treatments were evaluated: (1) Control: with no provision of chitosan; (2) $75 \mathrm{mg} / \mathrm{kg} \mathrm{BW}$; (3) $150 \mathrm{mg} / \mathrm{kg} \mathrm{BW}$; and (4) $225 \mathrm{mg} / \mathrm{kg} \mathrm{BW}$ of chitosan placed into the rumen through the fistula.

${ }^{\mathrm{B}}$ Linear (LIN) or quadratic (QUA) effects.

${ }^{\mathrm{C}}$ Cow body condition score was estimated using a five-point scale according to Wildman et al. (1982), from $1=$ emaciated to $5=$ obese.

energy efficiency of propionic fermentation is greater when compared with other VFA and can reduce energy diet losses through methane, which is associated with acetic and butyric acids production (Armentano 1992). However, changes in the proportions of VFA produced in the rumen, favouring increased propionate suggests that chitosan is affecting Gram-positive bacteria (McGuffey et al. 2001). Generally, chitosan has strong antimicrobial effect against Gram-positive rather than Gram-negative bacteria (Șenel and McClure 2004; Zhong et al. 2008). In addition, when the environmental $\mathrm{pH}$ is above chitosan $\mathrm{p} K_{\mathrm{a}}$ (6.3-6.5), hydrophobic and chelating effects of chitosan are responsible for the antimicrobial activity (Kong et al. 2010); however, in the present study, chitosan did not affect ruminal $\mathrm{pH}$. 
Chitosan reduced ruminal amino acids deamination. This occurred because of the reduction in ruminal concentration of branched-chain fatty acids as isobutyrate and isovalerate, which are produced in the rumen from deamination of isoleucine, leucine and valine (Chalupa 1980; Horton 1980). This fact could increase amino acids reaching the duodenum and consequently improve $\mathrm{N}$ efficiency utilisation. Chitosan increased $\mathrm{N}$ excreted in milk without altering $\mathrm{N}$ intake and improved $\mathrm{N}$ efficiency utilisation. Despite chitosan antimicrobial activity (Kong et al. 2010), the microbial protein synthesis was not altered and did not impair milk production in the present study.

Data of productive performance of ruminants provided with chitosan are limited in the literature, but chitosan appears to improve digestion and metabolism, especially by increasing ruminal propionate (Goiri et al. 2010; Araújo et al. 2015). Milk production, protein and lactose yield of cows were increased when chitosan was provided, mainly because of the greater ruminal propionate production and greater $\mathrm{CP}$ digestibility, which led to greater energy and $\mathrm{N}$ for milk synthesis.

\section{Conclusion}

Chitosan is a natural alternative modulator of ruminal fermentation, which increases ruminal propionate concentration, $\mathrm{N}$ utilisation efficiency and milk yield of dairy cows.

\section{Acknowledgements}

The authors acknowledge the University of Sao Paulo and the Dairy Cattle Research Laboratory, for providing all the physical structure and staff necessary for this study. In addition, the authors express appreciation to the Brazilian funding agency CAPES ('Coordenação de Aperfeiçoamento de Pessoal de Nivel Superior') for a scholarship to P. G. Paiva (grant number BEX3664/14), and James Shaffer, for the English review of this manuscript.

\section{References}

AOAC (2000) 'Official methods of analysis.' 17th edn. (Association of Official Analytical Chemists: Arlington, VA)

Araújo APC, Venturelli BC, Santos MCB, Gardinal R, Cônsolo NRB, Calomeni GD, Freitas JE, Barletta RV, Gandra JR, Paiva PG, Rennó FP (2015) Chitosan affects total nutrient digestion and ruminal fermentation in Nellore steers. Animal Feed Science and Technology 206, 114-118. doi:10.1016/j.anifeedsci.2015.05.016

Armentano LE (1992) Ruminant hepatic metabolism of volatile fatty acid, lactate and pyruvate. The Journal of Nutrition 122, 838-842.

Broderick GA, Kang JH (1980) Automated simultaneous determination of ammonia and total amino-acids in ruminal fluid and in vitro media. Journal of Dairy Science 63, 64-75. doi:10.3168/jds.S0022-0302(80) 82888-8

Calsamiglia S, Busquet M, Cardozo PW, Castillejos L, Ferret A (2007) Essential oils as modifiers of rumen microbial fermentation. Journal of Dairy Science 90, 2580-2595. doi:10.3168/jds.2006-644

Casali AO, Detmann E, Valadares Filho SC, Pereira JC, Henrique LT, Freitas SG, Paulino MF (2008) Influencia do tempo de incubacao e do tamanho de particulas sobre os teores de compostos indigestiveis em alimentos e fezes bovinas obtidas por procedimentos in situ. Revista Brasileira de Zootecnia 37, 335-342. doi:10.1590/S1516-359820080 00200021

Chalupa W (1980) Chemical control of rumen microbial metabolism. In 'Digestive physiology and metabolism in ruminants'. (Eds Y
Ruckebusch, P Thivend) pp. 325-347. (AVI Publishing Co.: Westport, CT)

Chen XB, Gomes MJ (1992) Estimation of microbial protein supply to sheep and cattle based on urinary excretion of purine derivatives - an overview of technical details. Bucksburnd, Aberdeen: International Feed Research Unit; Rowett Research Institute.

Chizzotti ML, Valadares Filho SC, Valadares RFD, Chizzotti FHM, Tedeschi LO (2008) Determination of creatinine excretion and evaluation of spot urine sampling in Holstein cattle. Livestock Science 113, 218-225. doi:10.1016/j.livsci.2007.03.013

Erwin ES, Marco GJ, Emery EM (1961) Volatile fatty acid analyses of blood and rumen fluid by gas chromatography. Journal of Dairy Science 44, 1768-1771. doi:10.3168/jds.S0022-0302(61)89956-6

Fujihara S, Yamaguchi M (1978) Effects of allopurinol 4-hydroxypyrazolo (3,4-d) pyrimidine on metabolism of allantoin in soybean plants. Plant Physiology 62, 134-138. doi:10.1104/pp.62.1.134

Getachew G, Makkar HPS, Becker K (2002) Tropical browses: contents of phenolic compounds, in vitro gas production and stoichiometric relationship between short chain fatty acid and in vitro gas production. The Journal of Agricultural Science 139, 341-352. doi:10.1017/S00 21859602002393

Goiri I, Oregui LM, Garcia-Rodriguez A (2009a) Dose-response effects of chitosans on in vitro rumen digestion and fermentation of mixtures differing in forage-to-concentrate ratios. Animal Feed Science and Technology 151, 215-227. doi:10.1016/j.anifeedsci.2009.01.016

Goiri I, Garcia-Rodriguez A, Oregui LM (2009b) Effect of chitosan on mixed ruminal microorganisms fermentation using the Rumen Simulation Technique (Rusitec). Animal Feed Science and Technology 152, 92-102. doi:10.1016/j.anifeedsci.2009.04.005

Goiri I, Oregui LM, Garcia-Rodriguez A (2010) Use of chitosans to modulate ruminal fermentation of 50:50 forage-to-concentrate diet in sheep. Journal of Animal Science 88, 749-755. doi:10.2527/jas.20092377

Hall MB (2000) Calculation of non-structural carbohydrate content of feeds that contain non-protein nitrogen. University of Florida, P.A-25 (Bulletin 339, April 2000)

Horton GMJ (1980) Use of feed additives to reduce ruminal methane production and deaminase activity in steers. Journal of Animal Science 50, 1160-1164.

Kong M, Chen XG, Xing K, Park HJ (2010) Antimicrobial properties of chitosan and mode of action: A state of the art review. International Journal of Food Microbiology 144, 51-63. doi:10.1016/j.ijfoodmicro. 2010.09.012

McGuffey RK, Richardson LF, Wilkinson JID (2001) Ionophores for dairy cattle: current status and future outlook. Journal of Dairy Science $\mathbf{8 4}$ (Suppl.), E194-E203. doi:10.3168/jds.S0022-0302(01)70218-4

Mertens DR, Allen M, Carmany J, Clegg J, Davidowicz A, Drouches M, Frank K, Gambin D, Garkie M, Gildemeister B, Jeffress D, Jeon CS, Jones D, Kaplan D, Kim GN, Kobata S, Main D, Moua X, Paul B, Robertson J, Tayson D, Thiex N, Williams J, Wolf JM (2002) Gravimetric determination of amylase-treated neutral detergent fibre in feeds with refluxing in beakers or crucibles: collaborative study. Journal of AOAC International 85, 1217-1240.

National Research Council (2001) 'Nutrient requirements of dairy cattle.' 7th edn. (National Academies Press, Washington, DC)

Nocek JE (1988) In situ and other methods to estimate ruminal protein and energy digestibility: A review. Journal of Dairy Science 71, 2051-2069. doi:10.3168/jds.S0022-0302(88)79781-7

Russell JB, Houlihan AJ (2003) Ionophore resistance of ruminal bacteria and its potential impact on human health. FEMS Microbiology Reviews 27, 65-74. doi:10.1016/S0168-6445(03)00019-6

Şenel S, McClure SJ (2004) Potential applications of chitosan in veterinay medicine. Advanced Drug Delivery Reviews 56, 1467-1480. doi:10.1016/ j.addr.2004.02.007 
Sklan DR, Ashkenazi R, Braun A, Devorin A, Tabori K (1992) Fatty acids, calcium soaps of fatty acids, and cotton seeds fed to high yielding cows. Journal of Dairy Science 75, 2463-2472. doi:10.3168/ jds.S0022-0302(92)78008-4

Wildman EE, Jones GM, Wagner PEA (1982) Dairy cow body condition system and its relationship to selected production characteristics. Journal of Dairy Science 65, 495-501. doi:10.3168/jds.S0022-0302 (82)82223-6
Yang CM, Russell JB (1993) Effect of monensin supplementation on ruminal ammonia accumulation in vivo and the numbers of amino acid-fermenting bacteria. Journal of Animal Science 71, 3470-3476.

Zhong Z, Xing R, Liu S, Wang L, Cai S, Li P (2008) Synthesis of acyl thiourea derivatives of chitosan and their antimicrobial activities in vitro. Carbohydrate Research 343, 566-570. doi:10.1016/j.carres. 2007.11.024 